\title{
Internal and External Factors That Influence Development of Childrens Independence
}

\author{
Endah Mulyani ${ }^{1, *}$, Nourma Yunita ${ }^{2}$, Siti Mudlikah ${ }^{3}$, Diani Octaviyanti \\ Handajani $^{4}$, Munisah ${ }^{5}$ \\ 1,2,3,4,5 Department of Midwifery, Faculty of Health, University Muhammadiyah Gresik \\ Jl. Proklamasi No.54 Trate Kabupaten Gresik. \\ Corresponding Email: endahmulyani@umg.ac.id
}

\begin{abstract}
The independence of children is the assets of childrens to become prime human resource, independence not to depend on others is one of the steps that must be trained from an early age. This study is a cross-sectional analytic study that was conducted to identify the external and internal factors that influence development of childrens independence. The study was performed on mother who had 3-5 years old child, simple random sampling selected through from 170 mother in Al-Wahyu Kindergarten School. 119 mothers were selected study's respondents. The data were collected through questionnaires. The results of the study was obtained using mulitiple logistic regression test and it showed that the factors that influence development of childrens independence in AlWahyu Kindergarten School, Surabaya, were gender of the child as internal factor ( $\mathrm{OR}=2.91 ; 95 \% \mathrm{CI}=1.27$ to 6.64; $\mathrm{p}=0.011)$; parenting style as external factor $(\mathrm{OR}=1.35 ; 95 \% \mathrm{CI}=1.10$ to $1.65 ; \mathrm{p}=0.004)$ and the number of children in the family $(\mathrm{OR}=0.48 ; 95 \% \mathrm{CI}=0.24$ to $0.94 ; \mathrm{p}=0.034)$. From the results it can be concluded that internal and external factors have a related influence so that right parenting style that is in accordance with the gender and position of the child in the family will increase the childs independence.
\end{abstract}

Keywords: parenting style, independence of children

\section{INTRODUCTION}

Independence is the initial capital of development and creativity of a person other than that independence is the capital of survival. In pre-school age children who are not trained to have independence since childhood, they will grow up to be tailors who tend to be afraid to make decisions and make innovations and this will hinder one's progress.

Based on the research results, it is stated that almost $45 \%$ of children under five in developing countries experience growth and development disorders. The prevalence rate of independence of pre-school children in developing countries $38 \%$ of preschool children is dependent on parents and caregivers. The independence of children at preschool age is divided into 2 , namely, physical independence and psychological independence. Psychological independence is the ability of preschool-aged individuals to make decisions and solve problems on their own. The preschool period is a golden period of child development so it is hoped that at this age the child's independence has been trained and formed in the family will be a factor in the independence and independence of children because the existing culture affects the way parents care for and raise their children. [3]

Based on the results of a preliminary study conducted by interviewing the principal, it was found that $20 \%$ of children experienced tardiness or insufficient. independently. So that in this study the researchers were interested in seeing the influence of age, education, mother's employment status, number of children in the family. The independence of children is influenced by several factors, namely the independence of internal factors and external factors. Internal factors are factors from within the individual while external factors are factors that come from outside the child. Internal factors include gender and physical condition of children, while external factors are parenting styles, number of children in the family and experience factors in life [1].

Based on research, the aggressive attitude of a child is caused by the parenting style applied by his parents [2]. Culture, dominant parenting styles and gender on the level of independence of children aged 3-5 years at TK Al Wahyu Surabaya. 


\section{RESEARCH METHODS}

This study used an analytic design with a cross sectional approach. The population in this study were 170 mothers who have children aged 3-5 years at Al-Wahyu Kindergarten Surabaya. Data collection was carried out during August 2020.

The sample size in the study was 119 mothers who were taken randomly using simple random sampling technique. The independent variables in this study were maternal age, mother's education, maternal occupation, number of children in the family, parenting style and gender. The dependent variable is the child's level of independence. The data was collected by using questionnaires which were distributed online via google form with the help of the school. Measurement of parenting style variables using the Parenting Style Dimension Questionnaire (PSDQ) This questionnaire has been widely used in various studies so there is no doubt for its validity and reliability. Measuring the level of children's independence using a research questionnaire [4] which has passed the validity and reliability test.

The data that has been collected will be processed and analyzed using statistical tests in several stages. The first stage of data will be analyzed using univariate analysis techniques which aim to see the frequency distribution of the characteristics of the respondents in each variable, then the data will be analyzed using bivariate analysis techniques, namely analysis that aims to see the effect of independent variables on the level of children's independence. At this stage the statistical test used is regression. simple logistics. The analysis technique at the last stage is the multivariate analysis technique using multiple logistic regression tests, this analysis is carried out with the aim to see the effect of independent variables on the level of independence of the child simultaneously

\section{RESULTS}

\subsection{Frequency distribution of respondent characteristics}

TABLE 1. Univariate Analysis Results with Descriptive Test

\begin{tabular}{|l|c|c|}
\hline \multicolumn{1}{|c|}{ Variable } & n & \% \\
\hline Age Mother & & \\
\hline$\leq 30$ years & 43 & 36.1 \\
\hline$>$ 30 years & 76 & 63.9 \\
\hline Mother Education & & \\
\hline Primary & 90 & 75.6 \\
\hline
\end{tabular}

\begin{tabular}{|c|c|c|}
\hline Variable & $\mathbf{n}$ & $\%$ \\
\hline Height & 29 & 24.4 \\
\hline \multicolumn{3}{|l|}{$\begin{array}{l}\text { Occupational Status of } \\
\text { Mother }\end{array}$} \\
\hline Not Working & 66 & 55.5 \\
\hline Working & 53 & 44.5 \\
\hline \multicolumn{3}{|l|}{$\begin{array}{l}\text { Number of Children in the } \\
\text { Family }\end{array}$} \\
\hline 1 child & 24 & 20.2 \\
\hline 2 children & 68 & 57.1 \\
\hline$>3$ children & 27 & 22.7 \\
\hline \multicolumn{3}{|l|}{ Gender } \\
\hline Boy & 65 & 54.6 \\
\hline Girl & 54 & 45.4 \\
\hline \multicolumn{3}{|l|}{ Parenting Dominant } \\
\hline Demokratif & 74 & 62.2 \\
\hline Demokratif-Authoritarian & 8 & 6.7 \\
\hline Demokratif-Permissive & 30 & 25.2 \\
\hline $\begin{array}{l}\text { Demokratif-Authoritarian- } \\
\text { Permissive }\end{array}$ & 7 & 5.9 \\
\hline \multicolumn{3}{|l|}{ Independence Children } \\
\hline Independence & 65 & 54.6 \\
\hline Interdependence & 54 & 45.4 \\
\hline
\end{tabular}

Based on Table 1, we can see most of the respondents aged $>30$ years, namely $63.9 \%$ and almost all respondents have a level of basic education yes that graduated from high school by $75.6 \%$ and most of the respondents also work, namely by $55.5 \%$. Most of the respondents had 2 children in their families, namely $57.1 \%$. The gender of the respondent's child was mostly male, namely $54.6 \%$. Most of the respondents have democratic parenting, which is $62.2 \%$. Most of the children of the respondents were also not independent, namely $54.6 \%$

\subsection{The effect of independent variables on the level of children's independence}


TABLE 2. Results of Bivariate Analysis with Simple Logistic Regression Test

\begin{tabular}{|c|c|c|c|c|c|c|c|c|}
\hline \multirow{4}{*}{$\begin{array}{c}\text { Variab } \\
\text { les } \\
\text { Indepe } \\
\text { ndent }\end{array}$} & \multirow{2}{*}{\multicolumn{4}{|c|}{ Child Independence }} & \\
\hline & & & & & \multirow{2}{*}{\multicolumn{2}{|c|}{ Total }} & \multirow{3}{*}{$\begin{array}{c}P- \\
v a \\
l u \\
e\end{array}$} & \multirow{3}{*}{$\begin{array}{l}\mathbf{O} \\
\mathbf{R}\end{array}$} \\
\hline & \multicolumn{2}{|c|}{$\begin{array}{l}\text { Interdepe } \\
\text { ndence }\end{array}$} & \multicolumn{2}{|c|}{$\begin{array}{c}\text { Indepen } \\
\text { dence }\end{array}$} & & & & \\
\hline & $\mathbf{F}$ & $\%$ & $\mathbf{F}$ & $\%$ & $\mathbf{F}$ & $\%$ & & \\
\hline \multicolumn{9}{|l|}{$\begin{array}{l}\text { Mater } \\
\text { nal } \\
\text { Age }\end{array}$} \\
\hline$\leq 30$ & 26 & 60.5 & 1 & 39. & 4 & 1 & \multirow{3}{*}{$\begin{array}{c}0 . \\
33 \\
6\end{array}$} & \multirow{3}{*}{$\begin{array}{l}1 . \\
4 \\
5\end{array}$} \\
\hline years & & & 7 & 5 & 3 & $\begin{array}{l}0 \\
0\end{array}$ & & \\
\hline $\begin{array}{l}>30 \\
\text { years }\end{array}$ & 39 & 51.3 & $\begin{array}{l}3 \\
7\end{array}$ & $\begin{array}{c}48 . \\
7\end{array}$ & $\begin{array}{l}7 \\
6\end{array}$ & $\begin{array}{l}1 \\
0 \\
0\end{array}$ & & \\
\hline $\begin{array}{l}\text { Mothe } \\
\mathbf{r} \\
\text { Educa } \\
\text { tion }\end{array}$ & & & & & & & & \\
\hline $\begin{array}{l}\text { Primar } \\
\mathrm{y}\end{array}$ & 46 & 51.1 & $\begin{array}{l}4 \\
4\end{array}$ & $\begin{array}{c}48 . \\
9\end{array}$ & $\begin{array}{l}9 \\
0\end{array}$ & $\begin{array}{l}1 \\
0 \\
0\end{array}$ & \multirow{2}{*}{$\begin{array}{c}0 . \\
17 \\
8\end{array}$} & \multirow{2}{*}{$\begin{array}{l}0 . \\
5 \\
5\end{array}$} \\
\hline High & 19 & 65.5 & $\begin{array}{l}1 \\
0\end{array}$ & $\begin{array}{c}34 . \\
5\end{array}$ & $\begin{array}{l}2 \\
9\end{array}$ & $\begin{array}{l}1 \\
0 \\
0 \\
\end{array}$ & & \\
\hline $\begin{array}{l}\text { Emplo } \\
\text { yment } \\
\text { Status } \\
\text { of } \\
\text { Mothe } \\
\text { r } \\
\end{array}$ & & & & & & & & \\
\hline $\begin{array}{l}\text { Not } \\
\text { Worki } \\
\text { ng }\end{array}$ & 39 & 59.1 & $\begin{array}{l}2 \\
7\end{array}$ & $\begin{array}{c}40 . \\
9\end{array}$ & $\begin{array}{l}6 \\
6\end{array}$ & $\begin{array}{l}1 \\
0 \\
0\end{array}$ & \multirow{2}{*}{$\begin{array}{c}0 . \\
27 \\
5\end{array}$} & \multirow{2}{*}{$\begin{array}{l}1 . \\
5\end{array}$} \\
\hline $\begin{array}{l}\text { Worki } \\
\text { ng }\end{array}$ & 26 & 49.1 & $\begin{array}{l}2 \\
7\end{array}$ & $\begin{array}{c}50 . \\
9\end{array}$ & $\begin{array}{l}5 \\
3\end{array}$ & $\begin{array}{l}1 \\
0 \\
0\end{array}$ & & \\
\hline $\begin{array}{l}\text { Numb } \\
\text { er of } \\
\text { Childr } \\
\text { en }\end{array}$ & & & & & & & & \\
\hline $\begin{array}{l}1 \\
\text { Child }\end{array}$ & 6 & 25 & $\begin{array}{l}1 \\
8\end{array}$ & 75 & $\begin{array}{l}2 \\
4\end{array}$ & $\begin{array}{l}1 \\
0 \\
0\end{array}$ & \multirow{3}{*}{$\begin{array}{c}0 . \\
00 \\
5\end{array}$} & \multirow{3}{*}{$\begin{array}{l}0 . \\
4 \\
1\end{array}$} \\
\hline $\begin{array}{l}2 \\
\text { childre } \\
\mathrm{n}\end{array}$ & 41 & 60.3 & $\begin{array}{l}2 \\
7\end{array}$ & $\begin{array}{c}39 . \\
7\end{array}$ & $\begin{array}{l}6 \\
8\end{array}$ & $\begin{array}{l}1 \\
0 \\
0\end{array}$ & & \\
\hline $\begin{array}{l}>3 \\
\text { childre } \\
\mathrm{n}\end{array}$ & 18 & 66.7 & 9 & $\begin{array}{c}33 . \\
3\end{array}$ & $\begin{array}{l}2 \\
7\end{array}$ & $\begin{array}{l}1 \\
0 \\
0\end{array}$ & & \\
\hline $\begin{array}{l}\text { Gende } \\
\mathbf{r}\end{array}$ & & & & & & & & \\
\hline
\end{tabular}

\begin{tabular}{|c|c|c|c|c|c|c|c|c|}
\hline Boys & 42 & 64.6 & $\begin{array}{l}2 \\
3\end{array}$ & $\begin{array}{c}35 . \\
4\end{array}$ & $\begin{array}{l}6 \\
5\end{array}$ & $\begin{array}{l}1 \\
0 \\
0\end{array}$ & 0. & 2. \\
\hline Girls & 23 & 42.6 & $\begin{array}{l}3 \\
1\end{array}$ & $\begin{array}{c}57 . \\
4\end{array}$ & $\begin{array}{l}5 \\
4\end{array}$ & $\begin{array}{l}1 \\
0 \\
0\end{array}$ & $\begin{array}{c}01 \\
7\end{array}$ & $\begin{array}{l}4 \\
6\end{array}$ \\
\hline $\begin{array}{l}\text { Domin } \\
\text { ant } \\
\text { Parent } \\
\text { ing } \\
\text { Patter } \\
\text { ns }\end{array}$ & & & & & & & & \\
\hline $\begin{array}{l}\text { Democ } \\
\text { ratic }\end{array}$ & 51 & 68.9 & $\begin{array}{l}2 \\
3\end{array}$ & $\begin{array}{c}31 . \\
1\end{array}$ & $\begin{array}{l}7 \\
4\end{array}$ & $\begin{array}{l}1 \\
0 \\
0\end{array}$ & \multirow{4}{*}{$\begin{array}{c}0 . \\
00 \\
0\end{array}$} & \multirow{4}{*}{$\begin{array}{l}1 . \\
4 \\
2\end{array}$} \\
\hline $\begin{array}{l}\text { Democ } \\
\text { ratic- } \\
\text { Author } \\
\text { itarian }\end{array}$ & 1 & 12.5 & 7 & $\begin{array}{c}87 . \\
5\end{array}$ & 8 & $\begin{array}{l}1 \\
0 \\
0\end{array}$ & & \\
\hline $\begin{array}{l}\text { Democ } \\
\text { ratic- } \\
\text { Permis } \\
\text { sive }\end{array}$ & 11 & 36.7 & $\begin{array}{l}1 \\
9\end{array}$ & $\begin{array}{c}63 . \\
3\end{array}$ & $\begin{array}{l}3 \\
0\end{array}$ & $\begin{array}{l}1 \\
0 \\
0\end{array}$ & & \\
\hline $\begin{array}{l}\text { Democ } \\
\text { ratic- } \\
\text { Author } \\
\text { itarian- } \\
\text { Permis } \\
\text { sive }\end{array}$ & 2 & 28.6 & 5 & $\begin{array}{c}71 . \\
4\end{array}$ & 7 & $\begin{array}{l}1 \\
0 \\
0\end{array}$ & & \\
\hline Total & 65 & 54.6 & $\begin{array}{l}5 \\
4\end{array}$ & $\begin{array}{c}45 . \\
4\end{array}$ & $\begin{array}{l}1 \\
1 \\
9 \\
\end{array}$ & $\begin{array}{l}1 \\
0 \\
0\end{array}$ & & \\
\hline
\end{tabular}

Based on table 2 we can know the effect each independent variable on the child's independence, based on the table it is found that The ones that have an influence on children's independence are the number of children in the family, the sex of the child and the dominant parenting style that the respondent applies to their children. This influence is indicated by the results of the analysis where the $p$-value $<0.05$. Based on the data, $p$-value $=0.005$ for the number of children in the family, $p$-value $=0.017$ for the gender of the child and $p$-value $=0.000$ for dominant parenting. Meanwhile, the variables that did not affect the level of child development were maternal age, mother's education and mother's employment status because the $\mathrm{p}$ value was $>0.05$. 


\subsection{Factors that influence the level of independence simultaneously}

TABEL 3. Multivariate Analysis With Multiple Logistic Regression Test

\begin{tabular}{|l|c|c|c|}
\hline \multicolumn{4}{|c|}{ Regression Test } \\
\hline $\begin{array}{l}\text { Number of children in } \\
\text { families }\end{array}$ & 0,034 & 2.91 & $\begin{array}{c}1279- \\
6649\end{array}$ \\
\hline children Gender & 0,011 & $0: 48$ & $\begin{array}{c}0248- \\
0947\end{array}$ \\
\hline dominant parenting & 0,004 & $1: 35$ & $\begin{array}{c}1101- \\
1655\end{array}$ \\
\hline
\end{tabular}

Based on table 3 it can be seen that the number of children in the family, the sex of the child and the pattern of parenting together affect the development of children's independence. The variable of the number of children in the family is the variable with the largest OR value, namely 2.91 , this shows that the number of children with only 1 in the family increases the likelihood of children showing an independent attitude by $2.91 \mathrm{x}$. For the variable with the smallest OR value is the gender of the child, namely 0.48 , this shows that the gender of boys has a $0.48 \mathrm{x}$ chance to show an independent attitude. Parenting has an OR value of 1.38 , this means that parents who apply democratic parenting are likely to have children who are not independent as much as $1.38 \mathrm{x}$.

\section{DISSUSSION}

\subsection{Internal factors}

The gender of the child is an internal factor that affects the level of independence of the child, the independence is an attitude that allows individuals to act freely on their own impulses for their own needs without the help of others [5]. At an early age girls are more obedient than boys, allowing girls to show more independent attitudes. Instinctively a woman has a greater sense of nurture and care than a man.

\subsection{External factors}

Factors that affect the level of children's independence include the number of children in the family and the parenting style adopted by the family [5]. The number of children in the family is related to the treatment of parents towards children, parents with only children will pay more attention to children [5]. Parenting patterns are how parents treat, care for, nurture, educate, guide, train which is manifested in the form of discipline, example, love, punishment and leadership through the words and actions of parents [6]. Parenting patterns of parents consist of 3 types, namely democratic, authoritarian and permissive [7]. The dimensions of democratic, permissive and orthoritarian parenting continuously have the power to build social structures and are routinely used to describe differences in parenting styles for each individual child's development [8]. The types of parenting adopted by parents can be seen by using the Parenting Style Dimension questionnaire [8]. Based on the results of the research conducted, almost all of them show a combination in applying parenting styles to their children ranging from democratic-authoritarian, democratic-permissive to a combination of the three. Parents who apply democratic-authoritarian parenting almost all of their children show this independence according to research [9], parents who liberate but control their children in exploring what their children's interests make them more independent.

Parenting style is an important key in the process of children's social development, through proper parenting, parents will provide them with education, practice, and introduce local culture and regulations for children to develop and accept the environment so that children can adapt to existing conditions. 10] The results of the above study show that mother's education does not affect children's independence. This is in accordance with research [11] which shows that mothers with high levels of education do not automatically have independent children. The age and work status of the respondents in this study also showed no influence on the level of children's independence.

Preschoolers have a developmental task of increasing initiative and guilt. Children at this age will learn rules and regulations that will shape their independence, this is a heavy duty for parents to be able to stimulate, approach and provide examples in the form of attitudes and actions towards children. [12].

\section{CONCLUSION}

The level of children's independence is influenced by gender, number children in the family and dominant parenting styles. The three of them together have an influence on the level of independence of the child, because parenting that is in accordance with the child's gender and condition can increase the child's independence. This study also shows that the characteristics of the mother, namely age, education and work status of the mother do not have an effect on the child's independence because independence is something that can be stimulated with the right action. 


\section{REFERENCES}

[1] M. Yuniarti, Sri. Andriyani, "Hubungan Pola Asuh Orang Tua Dengan Perkembangan Anak Prasekolah Di R.A Almardiyah Rajamandala Bulan Juli 2016," in Prosiding Seminar Nasional Ilmu Pengetahuan dan Teknologi Jendral Ahmad Yani (SNIJA), 2017, pp. 103-111.

[2] L. K. A, Lotfi Azimi. Sh, Vaziri. F, "Relationship between Maternal Parenting Style and Child's Aggressive Behavior," Procedia Soc. Behav. Sci., vol. 69, p. 127, 2012.

[3] C. Raeff, "Independence and Interdependence in Children's Developmental Experiences," Child Dev. Perspect., vol. 4, no. 1, pp. 31-36, 2010.

[4] N. P. Buana, "Kemandirian Anak Usia Prasekolah Ditinjau Dari Ibu Bekerja dan Tidak Bekerja," Universitas Muhammadiyah Malang, 2018.

[5] N. P. A. Anggraini, "Hubungan Pola Asuh Orang Tua Dengan Kemandirian Anak Usia 5 - 6 Tahun Di TK Tunas Bangsa Wiyono Pasawaran," Universitas Lampung, Bandar Lampung, 2018.

[6] K. Sunarty, "Hubungan Pola Asuh Orangtua Dan Kemandirian Anak," J. EST, vol. 2, no. 3, pp. 152-160, 2016.

[7] S. I. Umairoh, "Perbedaan Pola Asuh Orang Tua Terhadap Kemandirian Anak," J. Ilm. Tumbuh Kembang Anak Usia Dini, vol. 3, no. 3, pp. 157-165, 2018.

[8] S. A. Winsler, Adam. Madigan, Amy L. Aquiliono, "Correspondence Between Maternal And Paternal Parenting Styles In Early Childhood," Early Child. Res. Q., vol. 20, no. 1, pp. 1-12, 2005.

[9] A. bt A. Ghani, Faizah BA. Kamal, Suraya LBTA. Aziz, "The Implication Of Parenting Styles On The Akhlak Of Muslim Teenagers In The South Of Malaysia," Procedia Soc. Behav. Sci., vol. 114, pp. 761-765, 2014.

[10] J. Loudova, Irena. Lasek, "Parenting Style And Its Influence On The Personal And Moral Development Of The Child," Procedia Soc. Behav. Sci., vol. 174, pp. 1247-1254, 2015.

[11] E. Susanti, "Korelasi Tingkat Pendidikan Orang Tua Dan Pola Asuh Terhadap Kemandirian Anak Dalam Keluarga," J. Elektron. Mhs. Pendidik. Luar Sekol., vol. 6, no. 1, pp. 13-23, 2017.
[12] A. S. Dilanti, Maudi RF. Nurlelasari, Dewi. Nasution, "Pola Asuh Orang Tua dengan Perkembangan Sosialisasi dan Kemandirian Anak Usia 3 - 6 Tahun.," J. Bidan Pint., vol. 1, no. 1, pp. 1-11, 2020. 